\title{
Integrated management of natural resources in the Ecuador Highlands
}

\author{
Víctor Hugo Barrera ${ }^{1^{*}}$, Luis Orlando Escudero ${ }^{1}$, Jeffrey Alwang $^{2}$, Robert Andrade $^{2}$ \\ ${ }^{1}$ Instituto Nacional Autonomo de Investigaciones Agropecuarias, Quito, Ecuador; \\ *Corresponding Author: victor.barrera@iniap.gob.ec \\ ${ }^{2}$ Department of Agricultural and Applied Economics, Virginia Polytechnic Institute and State University, Blacksburg, USA; \\ alwangj@vt.edu
}

Received 18 March 2012; revised 27 April 2012; accepted 9 May 2012

\begin{abstract}
The Andean region of Ecuador is characterized by extreme poverty caused by low agricultural productivity, limited off-farm opportunities, and lack of access to markets. Poverty is related to degradation of natural resources as lagging agricultural productivity leads to incursions into fragile areas and use of erosive farming techniques on steeply sloped hillsides. Food production in fragile areas degrades soil and water resources, contributes to deforestation and loss of biodiversity, and reduces productive potential over time. This article discusses an agricultural development project designed to reduce the long-term downward development spiral in a watershed in Bolivar, Ecuador. The applied research program began with analysis of the state of soil resources, water, and biodiversity in the Chimbo sub-watershed. This information was used to design a plan with the input of local stake-holders to introduce environmentally friendly farming practices, soil and water conservation techniques, and various institutional innovations to promote resource conservation. This adaptive management program has been a solid success. This article describes the project, the challenges it faced, and how the process of adaptive management led to consensus among stakeholders about the appropriateness of sustainable management practices. We show how implementation of enhanced management practices contribute to reduced environmental vulnerability and improved welfare.
\end{abstract}

Keywords: Component; Natural Capital; Micro-Watershed; Systems Approach; Adaptive and Integrated Watershed Management

\section{INTRODUCTION}

The South American Andes are rife with environmen- tal problems related to human activities in fragile ecosystems. Andean populations are among the poorest in South America and often depend on rain-fed agriculture. The Andes form the headwaters of many of the great river systems of South America, and runoff and agriculture-related pollution can have negative consequences far from their sources. Humans are encroaching into fragile high plains as population pressures at lower elevations extend the agricultural frontier. Strategies to address these problems include more environmentally benign agricultural technologies in fragile areas, intensified production in less-fragile areas to reduce pressure on more fragile areas, and raising income-earning potential through less land-intensive activities. A key is to alter human behavior. Adaptive management processes show promise as means of altering behavior to attain agreedupon goals.

A watershed approach to natural resource management has been tried in different settings with varying degrees of success. Watersheds define natural linkages between human populations and their environments [1]. Watershed management is consistent with decentralized governance, which is gaining favor in Andean countries [2]. However, modern watershed management techniques require digitized data that are of limited availability in high mountain areas, and watershed management often requires the cooperation of competing and overlapping levels of local and regional government. A watershed management approach faces many challenges.

Any watershed approach must begin with the notion that watershed-level outcomes are products of individual decisions on fields spread across the catchment's area. These decisions reflect household livelihood strategies of allocating their physical, human, natural, and other assets to earn livings, increase well-being, and manage multiple risks [3]. Individual decisions have compound effects and impacts on aggregate economic and environmental outcomes result from a complex mosaic of economic, social, and physical networks that characterize all water- 
sheds. The driving factor is human decision making. Effective management must identify mechanisms for changing human activities and introduce options to raise incomes while mitigating negative environmental consequences.

Integrated adaptive watershed management is a relatively new concept in Ecuador, but it provides hope that some environmental problems can be addressed through consensus building. The 1970s-era focus of tops-down watershed management has evolved over time and newer concepts recognize the holistic nature of the relationship between land use, agricultural production, natural resource conservation, and reduction of contaminants. It also recognizes that watershed outcomes result from human decisions [4].

Our integrated watershed management program in the Chimbo sub-watershed in Bolivar Province is guided by four concepts: 1) Agricultural intensification can be consistent with sustainable natural resource management [5]; 2) Sustainable agricultural practices can contribute to preservation of bio-diversity [6]; 3) Increased bio-diversity can contribute to household food security by diversifying diets and reducing risks of crop failure [7]; and 4) Even the poorest of the poor are interested in and capable of adopting environmentally friendly technologies [6].

Evidence shows that these arguments are valid in the Ecuadorean highlands [8]. Ecuador's National Autonomous Agricultural Research Institute (INIAP) has engaged farmers in the Chimbo for many years and has found farmers to be receptive to solutions to natural resource problems [8]. Over time, INIAP has created important strategic alliances and generated broad support for integrated adaptive watershed management. INIAP now combines an integrated adaptive management approach with a livelihoods focus, recognizing that any effort to improve environmental conditions must also create economic space (i.e. provide sufficient incomes to maintain a family) for conservation actions.

The objectives of this paper are to describe the adaptive watershed management process, obstacles overcome during its implementation, and provide a preliminary assessment of program impacts. We describe the site, present our research methods, and identify specific innovations attributable to the research. We then discuss research findings with respect to returns to management practices and describe how the recommended practices have spread over time. The paper concludes by discussing lessons learned and how the adaptive management process can be applied to other areas.

\section{SITE DESCRIPTION}

The Chimbo River sub-watershed covers approximately $3.635 \mathrm{~km}^{2}$ (Figure 1); our program focuses on two micro-watersheds: Illangama and Alumbre. The Illangama micro-watershed covers $131 \mathrm{~km}^{2}$ and extends from

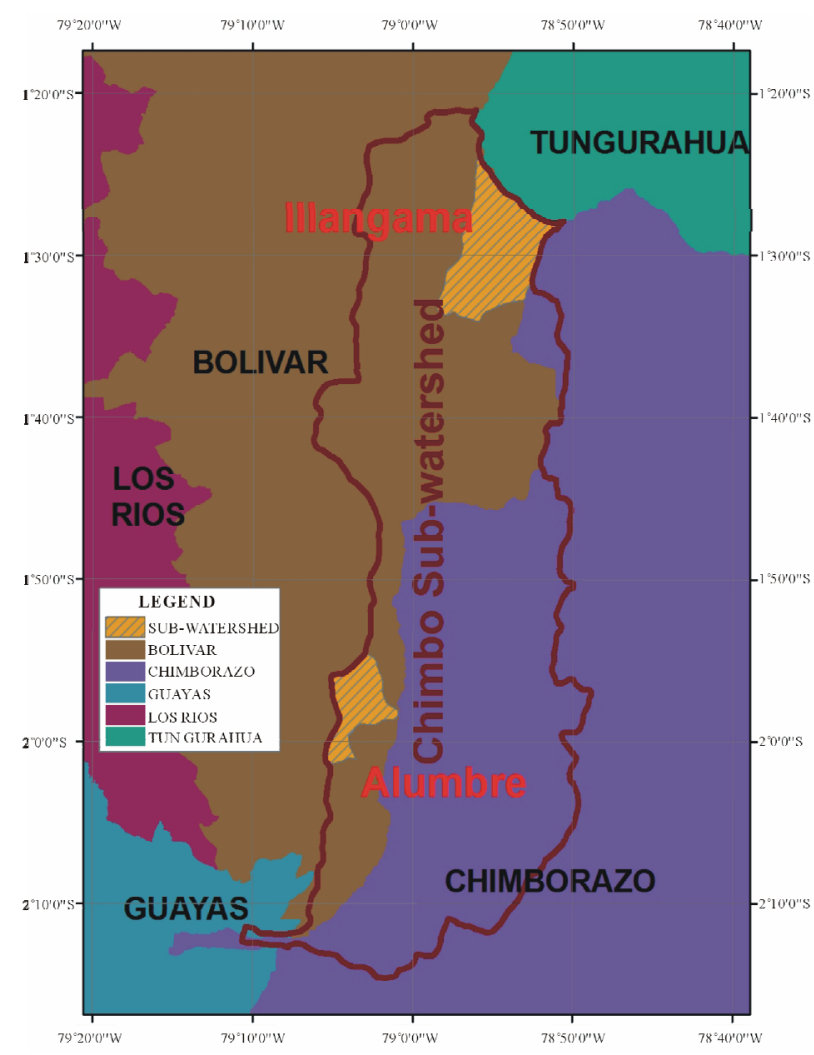

Figure 1. Location of study. The Chimbo River sub-watershedEcuador.

a latitude of $1^{\circ} 23^{\prime} 55.30^{\prime \prime S}$ through $34^{\prime} 4.80^{\prime \prime S}$ and from $78^{\circ} 50^{\prime} 39.38^{\prime \prime} \mathrm{W}$ to $78^{\circ} 58^{\prime} 29.52^{\prime \prime} \mathrm{W}$. The Alumbre covers 65 $\mathrm{km}^{2}$ and extends from $1^{\circ} 54^{\prime} 29.14^{\prime \prime S}$ to $2^{\circ} 11^{\prime} 36.90^{\prime \prime S}$ and from $79^{\circ} 0^{\prime} 22.20^{\prime \prime} \mathrm{W}$ to $79^{\circ} 6^{\prime} 4.41 " \mathrm{~W}$ [9]. The Illangama is between 2800 and 4500 masl, with agricultural activity found between 2800 and 3600 masl. The Alumbre area ranges from 2000 to 2800 masl with agriculture throughhout [10].

The watershed is characterized by social and economic conditions that threaten environmental sustainability and create long-term risks to human populations [11]. The area is among the poorest in Ecuador [12]. The river system flowing through the watershed provides about $40 \%$ of the total flow to the Guayas River, the largest system in Coastal Ecuador. Water quantity and quality has declined in recent years, partly due to upstream erosion, deforestation and expansion of the agricultural frontier into fragile highlands [13]. The highest (páramo) areas are reservoirs of clean water, and incursions into them have major downstream effects [14].

Households in the area depend on agriculture; more than $60 \%$ of the economically active population in Bolivar Province is dedicated to agriculture. Agriculture is characterized by small holdings, low productivity and environmental degradation (Table 1). Steep slopes, irregular and sudden rainfall, and infrequent use of cover 
Table 1. Conditions in Chimbo sub-watershed.

\begin{tabular}{|c|c|}
\hline Agro-ecological conditions & Productive activities \\
\hline $\begin{array}{l}\text { Illangama } \\
\text { - Region: Páramo and Andean mesa } \\
\text { - Life zones: Subalpine or boreal, montain, low mountain } \\
\text { and cool temperate } \\
\text { - Temperature }{ }^{\circ} \mathrm{C}: 7 \text { - } 13 \\
\text { - Altitude } \mathrm{m}: 2800-5000 \\
\text { - }\end{array}$ & $\begin{array}{l}\text { - Agriculture-potato (Solanum tuberosum), pasture, quinoa (Chenopodium quinoa), } \\
\text { faba (Vicia faba), chocho (Lupinus mutabilis) and barley (Hordeum vulgare); } \\
\text { - Animal production—cattle, swine, sheep and guinea pigs; } \\
\text { - Tourism, artisan production, commerce, cheese production and sales. }\end{array}$ \\
\hline $\begin{array}{l}\text { Alumbre } \\
\text { - Region: Andean mesa and subtropical } \\
\text { - Life zone: Low mountain and pre mountain } \\
\text { - Temperature }{ }^{\circ} \mathrm{C}: 15-19 \\
\text { - Altitude } \mathrm{m}: 2000-2800 \\
\text { - Annual rainfall: } 750-1400 \mathrm{~mm}\end{array}$ & $\begin{array}{l}\text { - Agriculture-maize (Zea mays), beans (Phaseolus vulgaris), peas (Pisum sativum), } \\
\text { blackberry (Rubus glaucus), tree tomato (Ciphomandrea betacea), vine tomatoes } \\
\text { (Lycopersicum esculentum); } \\
\text { - Animal production-poultry, swine; } \\
\text { - Agro-industry-medicinal plants, cacao (Theobroma cacao), organic coffee } \\
\text { (Coffea arabica); } \\
\text { - Tourism, small-scale commerce, artisanal production. }\end{array}$ \\
\hline
\end{tabular}

Source: INIAP-SANREM CRSP-SENACYT, 2006.

crops and other means of conserving soils cause severe soil erosion.

\section{RESEARCH METHODS AND PROCESS}

The program was structured around an adaptive watershed management conceptual framework. This framework begins with the watershed as a geographic entity and recognizes that actors within the watershed make decisions that affect the entire watershed. The adaptive management framework is well-known [15] but has rarely been applied in a developing country context. It begins with an assessment of conditions and identification of problems faced by actors in the watershed. Stakeholders are engaged in goal-setting, and research is designed to address obstacles to achieving goals. Research findings are then used in a participatory process with stakeholders to produce watershed plans. These plans are implemented and outcomes are monitored. Monitoring could lead to changes in plans over time, and the adaptive cycle begins again. We introduce two innovations to this framework: Plans are adapted on a regular basis as the research base and acceptance of it grows, and the land-use plans include consideration of household decision making and how decisions create impact across multiple systems within the watershed.

The household decision process reflects livelihood choices. A livelihood refers to the capabilities, assets (stores, resources, claims, access), and activities required for a means of living [16], or how labor, land, and other assets are distributed among productive and reproductive activities. The decision to adopt a livelihood is based on the household asset base; available alternatives; institutional, policy, and social environments; access to information; and the natural environment. Asset allocation decisions have effects on household wellbeing, the abil- ity to save and invest, and the natural environment. For example, adoption of a maize technology affects labor and land allocations, income, risk exposure, and may affect erosion, runoff, and future soil quality. All these outcomes were identified as important during implementation of the adaptive management process.

The management program was built on four dimensions: communication, coordination, compromise and cooperation. The project facilitated movement along these dimensions through regular community meetings and a process of participatory research. Interactions helped generate consensus about key problems and solutions most likely to be successful.

Our assessment began with a participatory rural appraisal (PRA) to identify productive activities, assets, and perceptions about environmental conditions. The PRA was followed by a statistically representative household survey that collected information from 286 families. The survey covered household demographics, assets, sources of income, agricultural practices and others. These data were used to categorize households into livelihood typologies and conduct analysis of household decision-making processes. Survey observations were georeferenced, which allowed us to overlay survey information with agro-ecological, soils, infrastructure and other information in a GIS. The GIS was used to create thematic maps for the community engagement process, and to inform and structure research.

Emphasis was placed on identifying alternatives and evaluating them through hands-on research. For example, conversion of lands to permanent pasture or reversion to woodlands was not initially viewed as desirable. An assessment of biodiversity, together with research on alternatives to reduce erosion on productive lands, helped convince stakeholders that a combination of reversion together with adoption of erosion control practices in the 
most erosion-sensitive areas would help meet objectives about which consensus had been reached. Similar research efforts were undertaken to help find more effective soil fertility management regimes, more environmentally benign pest control methods, etc.

Livelihoods and their diversity: The baseline survey and information from the PRA were used to identify livelihood clusters. A quantitative hierarchical (data based) clustering method $[17,18]$ was combined with expert opinion to create these clusters. The livelihood clusters can be thought of as groupings of households with similar asset bases and different means of combining them to earn incomes. Some clusters were exclusively agriculture, others rely on off-farm incomes, and others on remittances from outside the area [19].

Water quality analysis: Early in the process, stakeholders decided that water quality should be monitored. Monitoring results were used to evaluate impacts of land-use changes on water quality. We measured bioindicators (macro-invertebrates), physical-chemical compositions, and micro-biological parameters [20]. This monitoring helped engage community members and built ownership of the research. Key macro-invertebrates were identified in exercises with local school children during 2006 and 2007; subsequent monitoring was incorporated into the local curriculum [20]. Monthly chemical analysis begins with samples being extracted by community members and sent to Quito for detailed analysis. Nitrate, phosphorus, total solids, temperature, $\mathrm{pH}$, conductivity, fecal coliform, and total coliform are all measured. Data on rainfall and stream flows are being collected and used to calibrate our watershed models (mainly the Soil and Water Assessment Tool-SWAT).

Biodiversity assessment: The PRA indicated that stakeholders were not aware of biodiversity or its importance. Early on, an assessment activity evaluated the richness and diversity of plant and animal species. The focus was on remaining natural woodlands and areas where water recharge occurs (mainly at upper elevations). The assessment incorporated local knowledge about the value, uses and abundance of native plant and animal species. Stakeholders helped transect the study area, and collect photographic and physical evidence. Evidence was classified and categorized at the National Herbarium in Quito. Strategic transects were also undertaken in remnant woodlands and areas of high vulnerability [21].

Physical and environmental vulnerability: We stratified our on-farm agronomic research (on pilot farms) according to an index of physical vulnerability which included six parameters: slope, vegetative coverage, rainfall frequency and intensity, wind intensity, seasonal variability and soil texture. These indicators were selected following focus group discussions with technicians and local farmers. The index takes a value between 0 and 1 , with 0 signifying no vulnerability and 1 representing areas of extreme vulnerability. The index was especially useful in helping producers understand linkages between farming practices, soil loss, and subsequent off-farm damages. Farmers had their parcels classified and the index values and information on actual land use were incorporated into the GIS. This information was used to identify environmental hot-spots and to inform subsequent land use plans.

Design of environmentally friendly alternatives: The program selected 13 production systems for research on more sustainable practices. All the practices were consistent with livelihood clusters. Illangama systems revolved around a well-established potato-dairy rotation, while in Alumbre maize-beans predominate (Table 2). Trials were established on pilot farms to evaluate impacts on income, labor use, environmental degradation, etc. of these practices. Best Management Practices (BMP) were targeted for implementation in high-vulnerability areas (Table 2). Farm and watershed-wide plans were created following consensus-building exercises with stakeholders.

\section{RESULTS AND DISCUSSION}

Four livelihood clusters were identified in the microwatersheds (Table 3). These reflect diversity in asset bases, use of productive resources, and impacts on the environment across the clusters [22].

In Illangama, most family incomes are based on agricultural production and work in agriculture off the farm. In contrast, Alumbre households use a combination of agricultural (own-farm) and diversified off-farm activities (Table 4). Households that are more dependent on agriculture and livestock possess and use more natural capital (mainly land) and physical capital (farm equipment and implements). Those that depend more on offfarm incomes have higher levels of human capital (reflected through education of adult members and children's participation in school). They also possess specialized skills, such as carpentry, masonry, etc. Households with greater quantities and qualities of natural and physical capital are most closely linked to agricultural markets and only infrequently participate in non-agricultural income-generating activities. They specialize in agriculture. Households with diversified off-farm incomes sources tend to be wealthiest and have fewer food security challenges.

\subsection{Water Quality Analysis}

Water quality analysis confirmed perceptions from the PRA that water quality is degraded in both watersheds. In Illangama, only two areas (Culebrillas and Quindigua) had water quality suitable for livestock consumption and 
Table 2. Sustainable agricultural production practices evaluated.

\begin{tabular}{|c|c|}
\hline Illangama & Alumbre \\
\hline $\begin{array}{l}\text { Deviation ditches with milín grass (Phalaris tuberosa) and native } \\
\text { species; } \\
\text { - Improved rotations: Natural pasture and improved varieties of } \\
\text { potato-barley-faba, and quinoa; } \\
\text { - Live barriers with native species (yagual, tilo, romerillo, piquil, } \\
\text { chachacoma, aliso, higuerón, tilo); } \\
\text { - Chocho associated with improved pasture; } \\
\text { - Improved planting and harvest schedule (to manage water and } \\
\text { runoff); } \\
\text { - Cultivation in belts (wheat, barley) with improved varieties from } \\
\text { INIAP; } \\
\text { - Improved pastures with forage mixes of annual rye grass, } \\
\text { bluegrass, white and red clover, biannual and perennial rye grass. }\end{array}$ & $\begin{array}{l}\text { - Belt/strip cultivation (maize and climbing beans); } \\
\text { - } \text { give barriers with native species (nogal, alisos, siete cueros and } \\
\text { - Bench terraces and horticultural production; } \\
\text { - Fruit trees on contours to form live barriers (chirimoya, lemon, } \\
\text { orange, avocado and blackberry); } \\
\text { - Reduced tillage of beans and peas; } \\
\text { - Improved pastures with forage mixes of annual rye grass, bluegrass, } \\
\text { white and red clover, biannual and perennial rye grass; } \\
\text { - Crop rotations (improved varieties of): Hard maize-climbing/bush } \\
\text { beans. Evaluation of promising germplasm; } \\
\text { - Contour planting and introduction of alfalfa (Pennisetum sp.) in } \\
\text { strips. }\end{array}$ \\
\hline
\end{tabular}

Source: INIAP-SANREM CRSP-SENACYT, 2009.

Table 3. Livelihood clusters in sub-watershed Chimbo River-Ecuador.

\begin{tabular}{cccc}
\hline Livelihoods & Percent & Households & Members \\
\hline Diversified households (A) & 27 & 78 & 432 \\
Engaged in agricultural markets (B) & 37 & 105 & 576 \\
Rural non-farm economy (C) & 17 & 50 & 218 \\
Agricultural consumption and wage work (D) & 19 & 53 & 241 \\
Total & $\mathbf{1 0 0}$ & $\mathbf{2 8 6}$ & $\mathbf{1 , 4 6 7}$ \\
\hline
\end{tabular}

Source: Original analysis using household survey (Andrade, 2008).

Table 4. Summary statistics for main variables and livelihoods in Alumbre.

\begin{tabular}{|c|c|c|c|c|c|}
\hline \multirow{2}{*}{ Variables } & \multicolumn{4}{|c|}{ Livelihood } & \multirow{2}{*}{ ANOVA Sig. } \\
\hline & A & $\mathrm{B}$ & $\mathrm{C}$ & $\mathrm{D}$ & \\
\hline Micro-watershed alumbre $\%$ & 46 & 37 & 98 & 85 & $0.00^{* * *}$ \\
\hline Land holding (ha) & 3.82 & 6.79 & 3.59 & 3.64 & $0.00^{* * *}$ \\
\hline Irrigation access $\%$ & 23 & 33 & 6 & 9 & $0.00^{* * *}$ \\
\hline Value physical assets $\$$ & 2008 & 2348 & 856 & 496 & $0.00^{* * *}$ \\
\hline Distance to closest river $(\mathrm{km})$ & 1.12 & 0.86 & 2.05 & 1.58 & $0.00^{* * *}$ \\
\hline Distance to closest city $(\mathrm{km})$ & 7.21 & 7.58 & 3.61 & 5.17 & $0.00^{* * *}$ \\
\hline Participation in civil societies \% & 60 & 55 & 26 & 38 & $0.00^{* * *}$ \\
\hline Family members that migrate $\%$ & 71 & 39 & 54 & 13 & $0.00^{* * *}$ \\
\hline Mestizo households \% & 31 & 25 & 64 & 53 & $0.00^{* * *}$ \\
\hline Household size & 5.54 & 5.49 & 4.36 & 4.55 & $0.00^{* * *}$ \\
\hline Household head male \% & 88 & 90 & 82 & 72 & $0.02^{* *}$ \\
\hline Secondary education or plus $\%$ & 65 & 65 & 66 & 45 & $0.09^{*}$ \\
\hline Income per capita annually $\$$ & 653 & 785 & 839 & 288 & $0.00^{* * *}$ \\
\hline Expenditures per capita annually $\$$ & 254 & 252 & 252 & 184 & $0.03^{* *}$ \\
\hline
\end{tabular}

Source: Original analysis using household survey (Andrade, 2008). ${ }^{* * *}$ Significant at less than $1 \%$ level; ${ }^{* *}$ Significant at less than $5 \%$ level; ${ }^{*}$ Significant at less than $10 \%$ level. 
no sampling site had quality suitable for human consumption (Table 5). Fecal coliform contamination is a severe problem throughout the watershed; in $100 \%$ of the samples, we detected fecal coliform (E. coli). Highest values were found in Paltabamba and Quindigua and were related to the presence of trout lagoons near the sampling site and human waste. In other areas, livestock grazing in upstream water sources and agricultural runoff are key contributors to water quality degradation. Even at very high elevations in near-pristine environments, water quality is a problem.

In the lower-elevation Alumbre, physical chemical parameters fall within normal levels and are below national limits. Indicators of total solids and turbidity indicate significant siltation from erosion. Measures of fecal and total coliform indicate severe contamination (Table 5). Coliforms (E. coli and others) were detected in all the samples. The highest concentration of fecal coliform was detected in Chillanes (2240 UFC/100 cc), because it is found at the confluence of two smaller rivers carrying human wastewaters from urban centers. The second highest coliform count was found in Pacay, mainly because of high concentrations of cattle and swine near the river and human wastewaters.

\subsection{Biodiversity Assessment}

The micro-watersheds are distinguished by major differences in flora biodiversity. We identified around 162 tree and bush species in the area. In Illangama and Alumbre we identified 13 and 32 species, respectively, unique to that micro-watershed. Only 17 families of species were common to both micro-watersheds. Biodiversity is far richer in Alumbre, where the warmer climate is more conducive to species diversification.

Tree and bush species form a significant part of livelihood systems, particularly in Illangama. In Illangama, families have strong interest in species that can be used as animal forage, firewood and charcoal, and varieties with medicinal properties. They also use trees as live barriers in soil conservation structures, to extract dyes, and fibers for artisanal products. Alumbre residents are less aware of the uses of tree species, are unfamiliar with local names, and are mainly interested in trees for the exploitable wood they can produce.

The water quality and the biodiversity assessments were designed to highlight the fragility in high-altitude. The initial assessments showed that farmers' voice concerns about environmental quality, recognize that their productive practices can create environmental damage, and seek alternatives to resource-mining activities. The strongest concern for the environment was voiced by community members in the upper watershed who recognize environmental change such as variable rainfall patterns, less water availability and others. The assessments also strengthened linkages between the research team and community members; the participatory means of conducting them and open sharing of findings built ownership of the adaptive management process.

\subsection{Physical and Environmental Vulnerability}

In order to prioritize interventions, stakeholders need information on vulnerability and its variability over space. The GIS was combined with watershed modeling to generate a map of vulnerability to runoff. Results showed that about 4000 ha in Illangama and 2000 ha in Alumbre are extremely vulnerable to environmental damage. These areas needed special attention during the planning and management phases.

The vulnerability mapping exercise uncovered evidence of conflicts between ideal and actual land uses: Some of the most environmentally vulnerable lands are currently under intensive crop production. These areas should be reserved for conservation or reforested and managed sustainably. Research thus focused on the physical and economic/social consequences of less intensive

Table 5. Analysis of variance for microbiological indicators of water quality in sub-watershed Chimbo River-Ecuador.

\begin{tabular}{|c|c|c|c|c|c|}
\hline \multicolumn{3}{|c|}{ Illangama } & \multicolumn{3}{|c|}{ Alumbre } \\
\hline Collection sites & $\begin{array}{c}\text { UFC } \\
\text { E. coli /100 cc }\end{array}$ & $\begin{array}{l}\text { UFC colif. } \\
\text { total/100 cc }\end{array}$ & Collection sites & $\begin{array}{c}\text { UFC } \\
\text { E. coli/100 cc }\end{array}$ & $\begin{array}{l}\text { UFC colif. } \\
\text { total/100 cc }\end{array}$ \\
\hline Culebrillas (3495 m) & $550 \mathrm{c}$ & $4243 b$ & Chillanes (2274 m) & $2240 \mathrm{a}$ & $14,926 \mathrm{a}$ \\
\hline Quindigua (2930 m) & $1075 a b$ & 6793 a & Pacay (2240 m) & $840 \mathrm{ab}$ & $5746 \mathrm{~b}$ \\
\hline Paltabamba (2723 m) & $1244 \mathrm{a}$ & 6512 a & & & \\
\hline Meang $_{\mathrm{g}}$ & 867 & 5503 & $\operatorname{Mean}_{\mathrm{g}}$ & 1189 & 8340 \\
\hline $\mathbf{P}$ & 0.0136 & 0.0025 & $\mathbf{P}$ & 0.0155 & 0.0001 \\
\hline
\end{tabular}

Source: INIAP-SANREM CRSP-SENACYT, 2009. Letters indicate statistical significance $(\mathrm{P} \leq 0.05)$. 
uses on vulnerable lands. Such activities are especially critical in areas of water recharge. Two main challenges constrain efforts at conservation in these areas: Lack of finance to ensure that households can survive during the transition from intensive to extensive production (such as forestry or agro-forestry systems), and low rates of return in extensive production systems. Few own sufficient land resources to sustain a family on forestry production. Part of the problem is institutional; farmers have no means of capturing the off-farm benefits from less intensive land use. The team began negotiations with downstream govern ments to examine if these governments were willing to pay farmers to avoid downstream damages. These negotiations are ongoing, but downstream siltation is increasingly associated with costly flooding and there is strong interest in finding low-cost ways to avoid these damages.

\subsection{Design of Environmentally Friendly Farming Alternatives}

The research identified several environmentally friendly agricultural production options for farms in the Chimbo (Table 2). These alternatives increase productivity, enhance soil retention and improve soil health. They were tested on model farms, where farmers participated in site preparation, cultivation, and evaluation. Field days demonstrated the practices to farmers. Substantial adoption has occurred already and, given the success of the alternatives, we expect more widespread adoption as information becomes more widespread.

The pilot sites were established on farms with average sizes of 7.5 ha. In 2006, production systems included small pine forests, natural pasture, small areas of improved pasture, and potato production together with mashua (Tropaeolum tuberosum). At that time, the most vulnerable areas had been devoted to crop production. The research team designed a farm use plan incorporating improved cropping systems and farming practices, pastures and woodlands (Figure 2).

We tested and subsequently recommended use of improved potato varieties, faba beans, barley, quinoa and chocho. Conservation agriculture practices such as improved

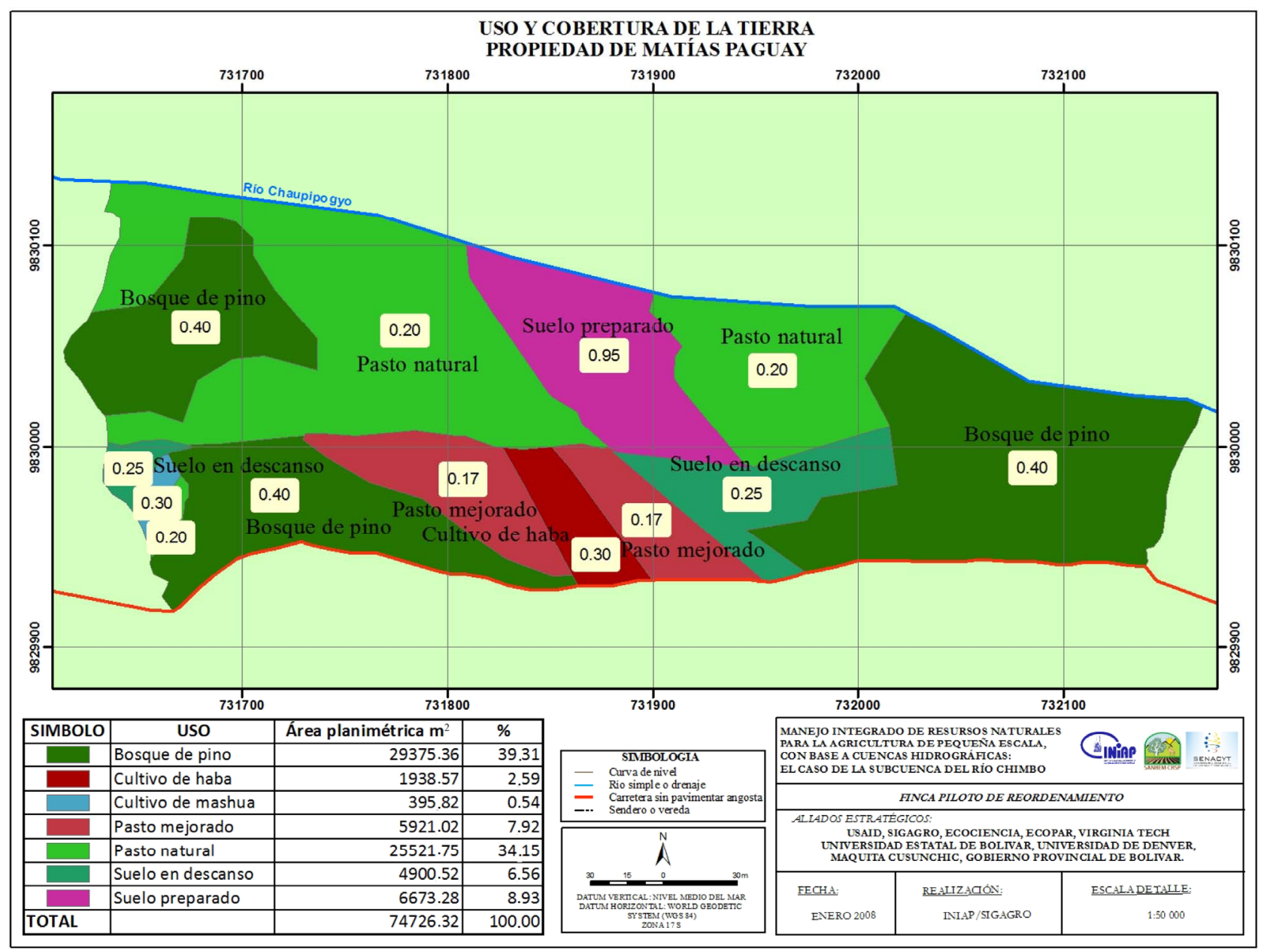

Figure 2. Land use map for model production system in Illangama, 2006. 
rotations, reduced tillage, and increased groundcover were included (Table 2). We also recommended in-situ conservation of native Andean tubers such as native potatoes, oca (Oxalis tuberosa), melloco (Ullucus tuberosus), mashua and carrot (Daucus caraota).

As of 2010, the project had been functioning for 5 years and it was possible to evaluate its impacts. This was done by transecting the sub-watersheds to measure the extent of adoption of the practices and computing changes in farm incomes associated with the practices. Table 6 shows an assessment of uptake of BMPs in Illangama and Alumbre.

In Illangama, net economic benefits have risen to about \$ 1921 per hectare per year, an increase of about
$65 \%$ compared to 2006. Improvements have resulted from incremental increases in yields of potatoes, faba beans, chocho, barley, quinoa and improved pasture. Soil management has changed dramatically as ground cover is more widespread throughout the year. Part of this change was caused by changes in relative prices; potato and other crop prices have become increasingly variable and farmers are moving toward dairy production with continuous pasture and other more environmentally suitable crops. Potato net profits have, however, grown by as much as $50 \%$, due to improved rotations and reduced pesticide use (a major cost of production). Use of late blight-resistant potato varieties, improved soil fertility and use of better-quality seeds help lower variable

Table 6. Changes in farming practices and uptake of BMPs, 2006-2010.

\begin{tabular}{|c|c|c|c|}
\hline Micro-watershed & BMP & 2006 & 2010 \\
\hline & Area under potatoes (ha) & $1.02(100)$ & $0.85(87)$ \\
\hline & Area under faba beans (ha) & $0.38(13)$ & $0.45(48)$ \\
\hline & Area under chocho (ha) & $0.60(4)$ & $0.50(35)$ \\
\hline & Area under barley (ha) & $0.59(5)$ & $0.65(65)$ \\
\hline & Area under quinoa (ha) & 0 & $0.15(40)$ \\
\hline & Area under natural grass (ha) & $2.13(48)$ & $1.80(35)$ \\
\hline & Area under improved pasture (ha) & $1.51(71)$ & $2.25(85)$ \\
\hline \multirow[t]{12}{*}{ Illangama } & Milk production (1/day) & 18 & 50 \\
\hline & Potato yields (t/ha) & 8.35 & 13.09 \\
\hline & Faba beans yields (t/ha) & 0.45 & 0.95 \\
\hline & Chocho yields (t/ha) & 0.60 & 1.15 \\
\hline & Barley yields (t/ha) & 0.73 & 1.30 \\
\hline & Quinoa yields (t/ha) & N/A & 1.20 \\
\hline & Pesticide used in potato production $(\$ / \mathrm{ha})$ & 289 & 186 \\
\hline & Net benefits (\$/year) & 1163 & 1921 \\
\hline & Area under white maize (ha) & $1.85(72)$ & $1.85(85)$ \\
\hline & Area under yellow maize (ha) & $1.18(5)$ & $1.18(15)$ \\
\hline & Area under maize/beans (ha) & $4.48(27)$ & $3.00(20)$ \\
\hline & Area under beans (ha) & $2.17(20)$ & $1.50(60)$ \\
\hline \multirow[t]{5}{*}{ Alumbre } & White maize yields (t/ha) & 0.44 & 1.10 \\
\hline & Yellow maize yields (t/ha) & 0.41 & 0.97 \\
\hline & Maize/beans yields (t/ha) & 0.57 & 0.91 \\
\hline & Beans yields (t/ha) & 0.40 & 0.88 \\
\hline & Net benefits (\$/year) & 898 & 1629 \\
\hline
\end{tabular}

Source: INIAP-SANREM CRSP-SENACYT, 2006-2010. Illangama: Percentage of farmers with the crop in each year (sample size: 117 in 2006 ; 250 in 2010). Alumbre: Percentage of farmers with the crop in each year (sample size: 169 in 2006; 80 in 2010). 
costs. Milk production per land unit grew by $122 \%$ due to improved forages, and better sanitation and feeding practices. Food security has also improved. Diversified grain sources broaden the dietary base, reduce risks from dependence on single crops, and increase energy and protein intake.

The data indicate impressive trends toward more diversified production, with increases in relatively new (to the area) products such as quinoa. Quinoa production has emerged, and the crop provides nutrition for home consumption and high prices in the market. As a result of all these changes, erosion is being reduced and water quality is improving.

In Alumbre, net benefits from agricultural production increased by $81 \%$ to $\$ 1629$ per hectare per year in 2010 . This increment was a product of increased yields of white maize, yellow maize and beans, resulting from improved management practices. The main engine was introduction of improved varieties, and more intensive management concentrated in less vulnerable and more productive areas. Planting densities have increased and integrated pest management practices have reduced input costs. Increased agro-diversity and lower profit risks (due to fewer purchased inputs) have also increased food security.

Use of vulnerability maps to guide land use planning has reduced production on most vulnerable lands and improved ecosystem services. Indicators of biodiversity, soil retention and water quality have improved alongside improvements in agricultural profitability. Farmers now concentrate productive activities on the most fertile and least vulnerable lands. Yield improvements and cost reductions allow farmers to earn higher incomes and simultaneously improve environmental conditions. Ability to observe farming practices on the pilot farms has built confidence in the new practices and they have naturally spread throughout the watershed. Concurrently, the study of biodiversity raised consciousness about the value of native species and led to planting and maintenance of these potential sources of biodiversity. These actions have improved environmental conditions and water availability

Prior to 2006, conservation practices in the area did not exist. Now, various practices are widely found, such as improved crop rotations, strip cultivation, deviation ditches, contour plowing, and use of live barriers. An indigenous innovation has led to the protection of deviation ditches with various local species. These include milín grass and native plants such as Quishuar, Yagual, Chachacoma, Romerillo, Aliso, Pumamaqui, Lupinus, Piquil. Contour cultivation is also widely practiced now in both watersheds, irrigation water management has improved and actions have been taken to protect areas of water recharge. This protection has involved replanting many of the native plants metioned above.

Table 7 summarizes results of the 2010 evaluation. Farmers in the Illangama watershed were more likely to apply all natural resource management methods, except for green fertilizer. Differences over time of use of conservation methods are statistically significant.

\subsection{Participatory Planning}

Our team identified local stakeholders, institutions and government and non-government partners to engage in participatory planning. Participants identified research themes and designed research activities and collaborated in on-farm trials. The process included meetings, workshops and information exchanges. Stakeholders immediately recognized the need for coordinated cross-sectorial actions and institutional change to increase the value of natural resources. A regular meeting of a project steering group was held; the group identified and promoted the

Table 7. Adoption of improved management practices, 2010.

\begin{tabular}{|c|c|c|c|c|c|}
\hline \multirow{2}{*}{ Method } & \multicolumn{2}{|c|}{ Alumbre } & \multicolumn{2}{|c|}{ Illangama } & \multirow{2}{*}{ p-value } \\
\hline & $\%$ Using & S.E. & $\%$ Using & S.E. & \\
\hline Deviation ditches ${ }^{*}$ & 5.02 & 1.42 & 31.25 & 5.21 & 0.0000 \\
\hline Contour plowing ${ }^{*}$ & 6.28 & 1.57 & 22.50 & 4.70 & 0.0015 \\
\hline Crop rotation $^{*}$ & 59.41 & 3.18 & 92.50 & 2.96 & 0.0000 \\
\hline Live barrier ${ }^{*}$ & 24.69 & 2.79 & 63.75 & 5.41 & 0.0000 \\
\hline Reduced till $^{*}$ & 26.36 & 2.86 & 76.25 & 4.79 & 0.0000 \\
\hline Green fertilizer & 7.11 & 1.67 & 6.25 & 2.72 & 0.7873 \\
\hline
\end{tabular}

*Denotes statistically significant differences between the watersheds ( 0.01 level). 
idea of integrated adaptive management. This group engaged local and Provincial Governments who are full partners in the process. The Provincial Government created a new unit for environmental management and linkages across government units has facilitated coordinated actions; our technical team has trained the Government's technical team and this strategic alliance has been strengthened over time. The alliance is important because the Provincial Government bears responsibility for creating and enforcing the regulatory and legal regime.

Our research agenda was arrived at after an arduous process of building consensus among stakeholders. Probably the most valuable research output at the start of the process was to help stakeholders understand and appreciate the value of their natural resources. This newfound appreciation of value has strengthened incentives for actions to promote soil retention and health, and to use native species as a contributor to this conservation. Native species of trees and bushes have been widely incorporated into live barriers to reduce water and wind erosion, and as lining biomass for deviation ditches. The team also helped identify a major source of reduced water supply and quality: Incursions into the upper páramo areas. As a result, we have built support for increased intensification at lower elevations and a sense of community-wide disapproval for those who exploit the pristine higher-elevation areas of the Illangama. Social pressure is having an effect.

Social capital has been strengthened in many ways. The participatory planning process is strengthening social networks in the region. In addition, training in biodiversity, natural resource valuation, and natural resource management has built networks of activists in both micro-watersheds. Efforts to understand the potential benefits of higher-valued market chains and obstacles to participation in them have helped identify how networks of producers can have more effects than individual actors. Subsequent efforts to build these networks have also reinforced local social capital.

\section{CONCLUSIONS}

The participatory land-use planning process led to a functioning watershed planning model. A key component of success was investment in agricultural and other research to increase incomes. Through this research, we are creating the economic space to address longer-term problems associated with natural resource degradation. The participatory process has built confidence among stakeholders who now largely buy into our larger program. Exposure to new technologies to raise incomes has helped build participation.
The nature of the watershed and the variety of stakeholders pushed us toward casting a large net; we made major efforts to involve institutions with any presence in the watersheds. Some of the less-recognized assets of our program: technical expertise, knowledge of successes and failures from elsewhere in Ecuador helped build bridges to institutions that in other cases might be less receptive to innovative ideas. For example, our ability to provide training for units of local governments helped legitimize our presence in the eyes of this important stakeholder.

Our adaptive watershed management project is less a political process and more a process of social learning and empowering community actions. A key barrier to effective local action was the Balkanization that predominated prior to our project: Different actors and stakeholders did not communicate and were even less likely to undertake coordinated actions. By casting a wide net and strongly encouraging participation, the project broke many of the barriers to collective action. Our training and participatory research efforts helped bring down these barriers and created a common consensual set of knowledge about actions. These programs brought down barriers and increased the capability to effect change.

Our most important lesson was the necessity to build consensus and engage stakeholder groups. The effort required to reach this point was substantial and involved tireless exercises in outreach, networking and stakeholder engagement. This process is long and one that may not show immediate results. However, the impact it eventually created was worth the effort. Communities in the watersheds now actively participate.

\section{RECOMMENDATIONS}

A first recommendation is to continue participatory consensus building. Efforts to engage community members in field experiments, in water quality data collection, and in the biodiversity assessment were especially helpful in gaining local ownership and building credibility for the entire project. We began with small steps and a massive amount of participation, and built in complexity as the process evolved. Wide participation also lowers labor costs associated with project activities.

A second recommendation is to incorporate a multisectorial approach. The primary objective of the project was to create sustainable means of natural resource management through adaptive watershed management. However, we documented the importance of research for more profitable technologies, for increased returns to producers through higher-valued chains (such as dairy production in the Illangama watershed), and for enhanced social and institutional capital. All these actions 
created space for and consensus about the need to conserve natural resources. Without them, the approach would not have been successful. We are still seeking a means of increasing farmer capture of value from offfarm benefits to on-farm investments (reduced erosion, enhanced water quality, enhanced biodiversity).

A final recommendation is that researchers should take risks. We began the project with skepticism about the adaptive management approach. We were concerned about the ability to generate data and make use of hightech tools such as GIS and SWAT. We wondered whether the community would accept research results from exotic tools. We found that although the data base is still inadequate and the SWAT results do not reflect reality as well as they might, the results are being used. GIS is probably the most effective tool in our arsenal for presenting results to stakeholders; they understand and can effectively interpret the maps we produce. These tools, while exotic, are not beyond the reach of a modest program in highland Ecuador.

\section{ACKNOWLEDGEMENTS}

This project was part of the SANREM CRSP, supported by the United States Agency for International Development and the generous support of the American people through Cooperative Agreement No. EPP-A-00-04-00013-00. We thank the people of the communities of the Alumbre and Illangama sub-watersheds for their participation in the project.

\section{REFERENCES}

[1] Doolette, J. and McGrath, W. (1990) Strategic issues in watershed development. In: Doolette, J. and McGrath, W., Eds., Watershed Development in Asia, World Bank Technical Paper No. 127, Washington DC.

[2] Guerra-García, G. and Sample, K. (2007) Policy and poverty in Andean countries. International IDEA, Stockholm.

[3] Siegel, P. and Alwang, J. (2004) An asset-based approach to social risk management: A conceptual framework. Social Protection Discussion Paper 9926. Social Protection Unit, Human Development Network, World Bank, Washington DC.

[4] Dourojeanni, A. and Jouravlev, A. (2001) Crisis in governability and water management: Challenges to implementation of agreed-upon recommendations. Economic commission for Latin America and the Caribbean (CEPAL). Series on Natural Resources and Infrastructure, Santiago.

[5] Scherr, S. and McNeely, J. (2004) Reconciling agriculture and wild biodiversity conservation: Policy and research challenges. In: Conservation and Sustainable Use of Agricultural Biodiversity: A Sourcebook, CIP-UPWARD, Lima, 46-55.

[6] Scherr, S. and Downward, A. (2000) "Spiral? Recent evidence on the relationship between poverty and natural resource degradation. Food Policy, 5, 479-498. doi:10.1016/S0306-9192(00)00022-1

[7] De Marco, J. and Monteiro Coelho, F. (2004) Services performed by the ecosystem: Forest remnants influence agricultural cultures' pollination and production. Biodiversity and Conservation, 13, 1245-1255. doi:10.1023/B:BIOC.0000019402.51193.e8

[8] Barrera, V., León-Velarde, C., Grijalva, J. and Chamorro, F. (2004) Management of the potato-pasture production system in Andean Ecuador: Technology options. Editorial ABYA, Technical Bulletin INIAP-CIP-PROMSA, Quito, $196 \mathrm{p}$.

[9] SIGAGRO (2008) Information on micro-watersheds in Alumbre and Illangama, Ecuador. Geographical Information System, Quito.

[10] INIAP (2008) Geographical Information System for the Chimbo River, Bolivar-Ecuador. Climate Monitoring. INIAP, Quito.

[11] Barrera, V., Alwang, J. and Cruz, E. (2008) Integrated management of natural resources for small-scale agriculture in the Chimbo river, Ecuador-lessons learned. INIAP SENACYT Information Bulletin No. 339, Quito.

[12] INEC-MAG (2002) III National Census of Agriculture: Resultados nacionales, provinciales y cantonales, instituto nacional de estadísticas y censos y ministerio de agricultura y ganadería. Quito.

[13] GPB (2004) Strategic plan for development, provincial government of Bolivar. Planning office, Guaranda, $224 \mathrm{p}$.

[14] Gallardo, G. (2000) Final report for the integrated management of natural resources in Watersheds. Quito, $220 \mathrm{p}$.

[15] Salafsky, N., Margoluis, R. and Redford, K. (2001) Adaptive management: A tool for conservation practitiones. Biodiversity Support Program, Washington DC.

[16] Chambers, R. and Conway, G. (1992) Sustainable rural livelihoods: Practical concepts for the 21 st century. IDS Discussion Paper 296. Institute for Development Studies, Brighton.

[17] Aldenderfer, M. and Blashfield, R. (1984) Cluster analysis; Series: Quantitative applications in the social science. SAGE University Paper, Beverly Hills.

[18] Ward, H. (1963) Hierarchical grouping to optimize and objective function. Journal of the American Statistical Association, 58, 236-244. doi:10.1080/01621459.1963.10500845

[19] Alwang, J., Barrera, V., Andrade, R., Hamilton, S. and Norton, G. (2009) Adaptive watershed management in the South American highlands: Learning and teaching on the Fly. In: SWCS, Ed., The Sciences and Art of Adaptive Management: Innovating for Sustainable Agriculture and Natural Resource Management. Ankenny, 209-227.

[20] Calles, J. (2007) Bioindicadores terrestres y acuáticos para las microcuencas de los ríos Illangama y Alumbre, provincia Bolívar. EcoCiencia, Quito, $30 \mathrm{p}$.

[21] Cruz, E. (2009) Study of biodiversity in microwater- sheds of Illangama and Alumbre, Ecuador. INIAP, Quito, 26 p. 
[22] Andrade, R. (2008) Household assets, Livelihood decisions and well-being in chimbo ecuador. Master of Sci- ence Thesis, Department of Agriculture and Applied Economics, Virginia Tech. 